\title{
Magic Realism in Gabriel Garcia Marquez's One Hundred Years of Solitude
}

\author{
B.J Geetha \\ Periyar University, India
}

\begin{abstract}
In his One Hundred Years of Solitude Gabriel Garcia Marquez through the arsenal of magic realism, deals with war, suffering, and death in the mid-1960 of Colombia which had witnessed two hundred thousand politically motivated deaths. The purpose behind portraying the politics of the region is to comment on how the nature of Latin American politics is towards absurdity, denial, and never-ending repetitions of tragedy. His magical flair is to merge fantastic with reality by introducing to the reader his Colombia, where myths, portents, and legends exist side by side with technology and modernity. These myths, along with other elements and events in the novel recount a large portion of Colombian history.
\end{abstract}

[Keywords: Colombia , Magic Realism; Marquez.]

Gabriel Garcia Marquez is rendered with a forte for blending the everyday with the miraculous, the historical with the fabulous, and psychological realism with surreal flights of fancy. He has proved himself as one among the pioneers of magic realism. His One Hundred Years of Solitude is a revolutionary novel that provides a looking glass into the thoughts and beliefs of its author, who chose to give a literary voice to Latin America.

Magic realism is a literary form in which odd, eerie, and dreamlike tales are related as if the events were commonplace. Magic realism is the opposite of the "once-upon-a-time" style of story-telling in which the author emphasizes the fantastic quality of imaginary events. In the world of magic realism, the narrator speaks of the surreal so naturally it becomes real. Magic realism in its literary and artistic applications aimed to re-imagine the world and its reality. It is not an escapist venture but rather an opportunity to see the fantastic in the everyday. There are multiple stylistic traits of magic realism. The key, however, is rejection of subjectivity and emotionalism, simultaneity of past, present and future and defamiliarisation. However, these traits distinguish magic realism from the fantasy genre. In fantasy novels, the created world must have an internal logic. Magic realism however, is not subject to natural or physical laws.

Gabriel uses the form of magical realism and the content derived from history and politics to address some of the most difficult and meaningful themes. He addresses war, suffering, and death with clarity and political slant. By the mid-1960's, Colombia had witnessed in excess of two hundred thousand politically motivated deaths. La Violencia, from 1946-66, can be

Rupkatha Journal on Interdisciplinary Studies in Humanities (ISSN 0975-2935), Vol 2, No 3, 2010

URL of the Issue: http://rupkatha.com/v2n3.php

URL of the article: http://rupkatha.com/V2/n3/MagicRealisminMarquez.pdf

(C) www.rupkatha.com 
broken into five stages: the revival of political violence before and after the presidential election of 1946, the popular urban upheavals generated by Gaitan's assassination, open guerrilla warfare, first against Conservative government of Ospina Perez, incomplete attempts at pacification and negotiation resulting from the Rojas Pinilla (who had ousted Laureano Gómez), and finally, disjointed fighting under the Liberal/Conservative coalition of the "National Front," from 1958 to 1975.

One Hundred Years of Solitude is an exemplary piece of magical realism, in which the supernatural is presented as mundane, and the mundane as supernatural or extraordinary. The novel presents a fictional story in a fictional setting. He carefully balances realistic elements of life, like poverty and housecleaning, with outrageous instances, like a levitating priest. There are many purposes of this. One is to introduce the reader to Marquez's Colombia, where myths, portents, and legends exist side by side with technology and modernity. Another reason for this leads the reader to question what is real and what is fantastic, especially in the realm of politics. It is to force to question the absurdity of our everyday lives. The twisted and meandering world of politics is under a great deal of scrutiny in this novel, particularly the chapters that deal with Colonel Aureliano Buendia. The world of politics is a gloomy one. There is little difference between the Liberals and the Conservatives; both parties kill and exploit the people. Although Marquez has a definite anti-capitalist bent, his purpose in portraying the politics of the region is not to be polemical. Instead, he comments on how the nature of Latin American politics is towards absurdity, denial, and never-ending repetitions of tragedy. The extraordinary events and characters are fabricated. However the message that Marquez intends to deliver explains a true history.

The politically charged violence characteristic of Colombia's history is paralleled in Colonel Aureliano Buendia who wages war against the Conservative who are facilitating the rise of foreign imperialist to power. The wealthy banana plantation set up their own dictatorial police force. The use of real events and Colombian history by Garcia Marquez makes One Hundred Years of Solitude an excellent example of magical realism. Not only are the events of the story an interweaving of reality and fiction, but the novel as a whole tells the history of Colombia from a critical perspective. In this way, the novel compresses several centuries of Latin American history into a manageable text.

The novel tells the story of 100 years in the lives of the Buendía family, who live in the coastal jungles of an unnamed South American country. It could equally be seen as the story of the town they found, Macondo. Yet another interpretation would be that it is the story of the life of Úrsula Buendía; all these things are tied intrinsically together. Had it been not for the title, it 
might pass unnoticed that it also contains examples of almost every type of loneliness and isolation that it is possible for human beings to suffer, from literal incarceration through blindness to the spiritual emptiness of repeated sexual conquests, or the happiness of isolation with the one you love. This is also the story of one hundred years in the life of Macondo and its inhabitants the story of the town's birth, development and death. Civil war and natural calamities plague this vital place whose populace fights to renew itself and survive.

In One Hundred Years of Solitude myth and history inadvertently overlap. The myth acts as a vehicle to transmit history to the reader. Marquez's novel can furthermore be referred to as anthropology, where truth is found in language and myth. There are three main mythical elements of the novel: classical stories alluding to foundations and origins, characters resembling mythical heroes, and supernatural elements. Magical realism is inherent in the novel is achieved by the constant intertwining of the ordinary with the extraordinary. This magical realism strikes at one's traditional sense of naturalistic fiction. There is something clearly magical about the world of Macondo. It is a state of mind as much as, or more than, a geographical place. For example, one learns very little about its actual physical layout. Furthermore, once in it, the reader must be prepared to meet whatever the imagination of the author presents to him or her.

Garcia Marquez blends real with the magical through the masterful use of tone and narration. He reinforces this effect through the unastonishing tone in which the book is written. This tone restricts the ability of the reader to question the events of the novel; however, it also causes the reader to call into question the limits of reality. Furthermore, maintaining the same narrator throughout the novel familiarizes the reader with his voice and makes the reader to become accustomed to the extraordinary events in the novel.

The inevitable and inescapable repetition of history is also dominant in Macondo. The protagonists are controlled by their pasts and the complexity of time. Throughout the novel the characters are visited by ghosts. The ghosts are symbols of the past and the haunting nature it has over Macondo. The ghosts and the displaced repetition that they evoke are, in fact, firmly grounded in the particular development of Latin American history. Ideological transfiguration ensured that Macondo and the Buendías always were ghosts to some extent, alienated and estranged from their own history, not only victims of the harsh reality of dependence and underdevelopment but also of the ideological illusions that haunt and reinforce such social conditions.

Garcia Marquez also illustrates magic realism with the description of his characters. In describing Melques, he says, "He is a fugitive from all 
plagues and catastrophes that had ever lashed mankind" (6). This a very difficult statement to believe, but Marquez continues: "He had survived pellagra in Persia, scurvy in the Malaysian archipelago, leprosy in Alexandria, beriberi in Japan, bubonic plague in Madagascar, an earthquake in Sicily, and a disastrous shipwreck in the Strait of Magellan" (6). Once again, he is able to make unbelievable ideas seem possible.

This novel never loses its capacity to surprise and delight us. No matter whom we meet, we quickly learn to expect the unexpected, the colourful, the original--from moments of evocative beauty, like the trail of butterflies, to the satiric, like the priest levitating to chocolate, to erotic scene of bawdy and prodigious sex, like characters whose farts are so strong they kill all the flowers in the house or man who runs through the house balancing beer bottles on his penis. The comic energy here is justly famous. The characters, for the most part, may be two-dimensional, and we may meet some of them only for a couple of pages, but there is throughout a sense of vitality and wonder at the world which makes this story hard to put down.

Like everything Marquez writes, there is some truth and much fiction in this tale. The truth in the tale is that One Hundred Years of Solitude is a very personal book for the author. It would not have been written if he had not experienced the kind of childhood he had. Marquez grew up with his maternal grandparents in Aracataca, Colombia. His grandparents were cousins who moved to Aracataca from Riohacha at the end of the War of a Thousand Days (1899-1902), a few years before a leaf storm. Marquez's childhood anecdotes tell of a big house full of ghosts, conversations in code, and relatives who could foretell their own deaths. It was also a house filled with guests and social events, shaded by almond trees and bursting with flowers. When Marquez's grandfather died, he was sent to live with his parents. In his grandfather's absence, his grandmother, who was blind, could no longer keep up the house. It fell into a state of ruin, and red ants destroyed the trees and flowers. Also early in his childhood, Marquez witnessed the massacre of striking banana workers at a plantation named Macondo at a train station. The government made every attempt to block information from the public and pacify the foreign plantation owners. Marquez was horrified, and even more horrified when he reached high school and learned that the event had been deleted from his history textbook.

Though Garcia Marquez's essentially a unique artist in handling magic realism. He also demonstrates that magical realism alone does not make a writer great. Marquez's imagination, human insight and literary skill, more than his genre, provide the best explanation for his art and popularity. As observed by one critic, "The magic realism in Garcia Marquez's novel forms a broad and diverse spectrum ranging from the literally extraordinary though 
nonetheless possible, to the farthest extremes of the physically fabulous and unlikely" (Bell-Villada 108). For example, Colonel Aureliano Buendia tries to commit suicide and shoots himself in the chest, but the bullet exits out his back without injuring a single organ.

Throughout One Hundred Years of Solitude, Garcia Marquez exaggerates events to gain fantasy. However, the exaggeration is almost always numerically specific and gives each occurrence a sense of reality, notes critic Bell-Villada (109). Examples of this are Colonel Buendia's thirtytwo defeated uprisings; the rainstorm that lasts four years, eleven months, and two days; and Fernanda's criss-crossed calendar of sex, containing exactly forty-two "available" days. Magic realism as a technique of transforming the fantastic into reality is represented by Garcia Marquez. He has the ability to turn the unbelievable into the believable, as demonstrated in One Hundred Years of Solitude.

One Hundred Years of Solitude includes realism and magic which seem at first to be opposites; they are, in fact, perfectly reconcilable. Both are necessary in order to convey Marquez's particular conception of the world. Marquez's novel reflects reality not as it is experienced by one observer, but as it is individually experienced by those with different backgrounds. These multiple perspectives are especially appropriate to the unique reality of Latin America-caught between modernity and pre-industrialization; torn by civil war, and ravaged by imperialism-where the experiences of people vary much more than they might in a more homogenous society. Through magical realism he conveys a reality that incorporates magic, superstition, religion and history which are unquestionably infused into the world.

\section{Bibliography}

Bell-Villada, Gabriel Garcia Marquez's One Hundred Years of Solitude: A Casebook Oxford: Oxford University, 2002.

Marquez, Gabrial Garcia. One Hundred Years of Solitude : Harper and Row Press, Colombia. 1967.

Martz. John D. Colombia A Contemporary Survey. The University of North Carolina Press: 1962

Rausch, Jane M. Colombia: Territorial Rule and Llanos Frontier. University Press of Florida: 1999.

Wood, Michael. Garcia Marquez 100 Years of Solitude. New York: Cambridge University Press, 1990

B. J. Geetha is an Assistant Professor in the Department of English, Periyar University, India. Email: geetprem05@gmail.com. 